\title{
Stres akademis berhubungan dengan kualitas hidup pada remaja
}

\author{
R Harvilia Safira Haryono ${ }^{1}$ Kurniasari $^{2}$
}

\begin{abstract}
ABSTRAK
LATAR BELAKANG

Masa remaja adalah periode usia yang berkisar dari 10-19 tahun. Remaja merupakan salah satu penentu indeks pembangunan manusia. Pembangunan ini bertujuan untuk meningkatkan kualitas hidup masyarakat. Kualitas hidup remaja dipengaruhi oleh banyak faktor, terutama faktor fisik dan psikologis. Pada remaja terjadi perubahan yang signifikan pada kedua faktor tersebut. Hal ini menyebabkan remaja menjadi rentan terhadap stres. Salah satu stres yang dapat dialami remaja adalah stres akademis. Stres akan mengakibatkan perubahan biokimia, psikologis, dan perilaku, kondisi ini dapat menyebabkan penurunan kesehatan fisik, psikologis, dan hubungan sosial sehingga mengakibatkan penurunan kualitas hidup. Penelitian ini bertujuan untuk menganalisa hubungan antara stress akademik dan kualitas hidup pada remaja.
\end{abstract}

\section{METODE}

Penelitian ini merupakan studi cross sectional dengan responden berjumlah 233 siswa di SMAN 1 Cileungsi, Kab. Bogor. Pengumpulan data menggunakan kuesioner Educational Stres Scale for Adolescent (ESSA) dan kuesioner Multidimensional Students' Life Satisfaction Scale-Adolescent (MSLSS). Analisis data dengan uji Chi-Square menggunakan program SPSS dengan tingkat kemaknaan sebesar 0,05.

\section{HASIL}

Dari 233 responden, 70\% berjenis kelamin perempuan, 30\% laki-laki, $15,5 \%$ tegolong stres ringan, $51,1 \%$ stres sedang, dan $33,5 \%$ stres berat, $50,2 \%$ memiliki kualitas hidup kurang dan 49,8\% kualitas hidup baik. Uji Chi-Square menunjukkan terdapat hubungan yang bermakna antara stres akademis dan kualitas hidup pada remaja $(\mathrm{p}=0,044)$.

\section{KESIMPULAN}

Stres akademis merupakan salah satu jenis stres yang dapat mempengaruhi kualitas hidup pada remaja.

Kata kunci : stres akademis, kualitas hidup, remaja

\author{
${ }^{1}$ Program Studi Kedokteran, \\ Fakultas Kedokteran, \\ Universitas Trisakti \\ 2 Departemen Farmakologi, \\ Fakultas Kedokteran, \\ Universitas Trisakti

\section{Korespondensi:} \\ dr. Kurniasari, M.Biomed \\ Departemen Farmakologi Fakultas \\ Kedokteran Universitas Universitas \\ Trisakti \\ Jalan Kyai Tapa No.1, Jakarta \\ Barat, DKI Jakarta 11440 \\ Telp: (021) 5672731 \\ E-mail: kurniasari@trisakti.ac.id
}

\author{
J Biomed Kes 2018;1(1):75-84 \\ DOI: 10.18051/JBiomedKes.2018. \\ v1.75-84 \\ pISSN: 2621-539X / eISSN: 2621-5470 \\ Artikel akses terbuka (open access) ini \\ didistribusikan di bawah lisensi Creative \\ Commons Attribution 4.0 International \\ (CC-BY 4.0)
}




\section{ABSTRACT}

\section{Academic stress associated with quality of life in adolescents}

\section{BACKGROUND}

Adolescence is a period of age that ranges from 10-19 years. Adolescence is one of the determinants of human development index. This development aims to improve the quality of life of the community. Quality of adolescent life is influenced by many factors, especially physical and psychological factors. In adolescence there is a significant change in both factors. This change causes teenagers to be vulnerable to stress. One of the stresses teenagers can experience is academic stress. Stress will lead to biochemical, psychological, and behavioral changes, this condition can lead to decreased physical, psychological, and social relationships resulting in decreased quality of life. Objective of this study is to analyze relationship between academic stress and quality of life in adolescents.

\section{METHODS}

A cross sectional study was conducted, with 233 students as in SMAN 1 Cileungsi, Kab. Bogor. Data was collected using Educational Stres Scale for Adolescent (ESSA) questionnaire and Multidimensional Students' Life Satisfaction Scale-Adolescent (MSLSS) questionnaire. Data analysis to determine the correlation was performed using Chi-Square on Statistical Package for Social Sciences (SPSS) with significance level 0,05.

\section{RESULT}

Among 233 respondents, 70\% girls, 30\% boys, 15,5\% low stress level, 51,1\% moderate stress level, and 33,5\% high stress level, $50,2 \%$ low quality of life dan $49,8 \%$ high quality of life. Chi-Square test shows that there is significant relationship between academic stres and quality of life in adolescence $(p=0,044)$.

\section{CONCLUSION}

There is significant relationship between academic stres and quality of life among adolescence.

Keywords : academic stress, quality of life, adolescents

\section{PENDAHULUAN}

Masa Remaja Menurut World Health Organization (WHO) adalah periode pertumbuhan dan pekembangan manusia yang terjadi setelah masa kanak kanak dan sebelum masa dewasa, yaitu dari usia 10 sampai 19 tahun. ${ }^{(1)}$ Di Indonesia, jumlah kelompok usia 10- 19 tahun menurut sensus penduduk 2010 berjumlah 43,5 juta jiwa atau sekitar 18\% dari total jumlah penduduk. ${ }^{(2)}$ Remaja yang sehat tidak hanya dilihat dari keadaan fisiknya saja, tetapi juga kondisi mental dan sosialnya. Apabila kondisi fisik, sosial dan mentalnya telah baik, maka akan tercipta kualitas hidup yang baik. ${ }^{(3)}$

Remaja merupakan salah satu penentu Indeks Pembangunan Manusia (IPM). IPM di Indonesia pada tahun 2015 adalah 0,689, yang termasuk dalam kategori pembangunan manusia tingkat menengah dan berada di peringkat 113 dari 188 negara. Pembangunan ini bertujuan untuk meningkatkan kesejahteraan masyarakat. ${ }^{(4)}$

Kesejahteraan masyarakat dapat diukur dengan Indeks Kualitas Hidup (IKH). World Health Organization (WHO) mendefinisikan kualitas hidup sebagai persepsi individu terhadap posisinya dalam konteks budaya dan nilai ditempat hidupnya serta hubungannya dengan tujuan hidup, harapan, standar dan pertimbangan individu ${ }^{(5)}$ Prevalensi kualitas hidup rendah pada remaja di Indonesia berdasarkan Riset Kesehatan Dasar di tahun 2007 sebesar 7\%. ${ }^{(6)}$

Kualitas hidup pada remaja dipengaruhi oleh berbagai faktor antara lain kesehatan fisik, kesehatan psikologis, persepsi diri, hubungan orang tua, finansial, lingkungan dan hubungan sosial. ${ }^{(7)}$ Faktor fisik dan psikologis mengalami perubahan yang signifikan pada remaja. Hal ini dapat menyebabkan remaja menjadi rentan terhadap stres. ${ }^{(8)}$

Salah satu stres yang bisa dialami oleh remaja adalah stres akademis. Stres akademis didefinisikan sebagai suatu stres yang berhubungan dengan kegiatan belajar siswa di sekolah. Pada beberapa hasil penelitian, diperoleh tingkat stres akademis di negara Asia seperti Vietnam $(51,3 \%)^{(9)}$, China $(66,7 \%)^{(10)}$, India $(63,5 \%)^{(11)}$ lebih tinggi dibanding negara maju seperti Australia (37\%) ${ }^{(12)}$ dan Norwegia $(33,92 \%))^{(13)}$

Stres adalah pengalaman emosional 
yang kurang menyenangkan dengan disertai perubahan biokimia, psiokologi, dan perilaku. ${ }^{(14)}$ Perubahan biokimia akibat stres berpengaruh terhadap sekresi hormon kortisol dan katekolamin, kondisi ini dapat mempengaruhi kesehatan fisik dan psikologis. Perubahan psikologis dapat menimbulkan perasaan cemas, lelah, sedih, panik, dan depresi, yang akhirnya akan menyebabkan penurunan kesejahteraan psikologis individu. Perubahan perilaku dapat berupa perubahan pola makan, menarik diri, hilangnya motivasi, menjadi pemarah, dan penyalahgunaan zat. Perubahan-perubahan tersebut menyebabkan penurunan kesehatan fisik, psikologis, dan hubungan sosial sehingga mengakibatkan penurunan kualitas hidup. ${ }^{(15,16)}$

Berdasarkan penelitian yang dilakukan oleh Awadh et al tentang stres dan kualitas hidup didapatkan hasil bahwa terdapat korelasi negatif yang signifikan. Hal ini berarti semakin tinggi tingkat stres semakin rendah kualitas hidup dari segi kesehatan fisik dan mental. (17) Hasil yang serupa diperoleh pada review sistematis oleh Ribeiro et al. Pada review tersebut dinyatakan bahwa terdapat hubungan negatif antara stres dan kualitas hidup. ${ }^{(18)}$ Penelitian Lyndon et al juga memperoleh hasil yang serupa, yaitu ditemukan korelasi negatif antara academic burnout dan kualitas hidup dengan proporsi kualitas hidup rendah akibat tekanan akademis sebesar 20\%. ${ }^{(19)}$ Hasil-hasil penelitian tersebut berbeda dengan penelitian yang dilakukan oleh Marshall et al yang menyatakan bahwa tidak terdapat korelasi antara stres dan kualitas hidup. ${ }^{(20)}$

Berdasarkan uraian yang telah dipaparkan sebelumnya terdapat perbedaan hasil dari penelitian-peneltian sebelumnya. Oleh karena itu, peneliti tertarik untuk melakukan penelitian ini yang bertujuan untuk menganalisa hubungan stres akademis dan kualitas hidup pada remaja.

\section{METODE}

Penelitian ini merupakan penelitian analitik observasional dengan metode Crosssectional di SMAN 1 Cileungsi, Kab. Bogor. Penelitian ini telah dilakukan pada bulan
Oktober - Desember 2017. Sampel yang digunakan adalah peserta didik kelas X, XI, XII di SMAN 1 Cileungsi yang berusia 18 tahun dan tidak memiliki riwayat kejadian stres berat dalam setahun terakhir seperti menderita penyakit kronis, kematian anggota keluarga atau teman dekat, perubahan dalam keseheatan atau keuangan keluarga, perubahan lingkungan tempat tinggal, dan berpindah sekolah.

Pengambilan sampel dilakukan secara cluster random sampling dan simple random sampling. Alur kerja penelitian dimulai dari menentukan besar sampel yang dibutuhkan dengan menggunakan rumus $\mathrm{n} 0=[\mathrm{Z} \alpha 2 \mathrm{X}$ p X q/d2] untuk menentukan besar sampel dari populasi infinit. Setelah itu, dihitung jumlah sampel untuk populasi finit dengan menggunakan rumus $\mathrm{n}=[\mathrm{n} 0 /$ $(1+(\mathrm{n} 0 / \mathrm{N})]$. Besar sampel yang diperlukan setelah penambahan dropout $15 \%$ adalah 233 responden. Kemudian dilanjutkan dengan menentukan subjek penelitian sesuai kriteria inklusi dan eksklusi.

Pengumpulan data dilakukan melalui wawancara untuk mendapatkan identitas dan karakteristik responden, lalu diikuti dengan pengisian kuesioner mengenai stres akademis dan kualitas hidup. Penilaian stres akademis dilakukan dengan menggunakan kuisioner Educational Stress Scale for Adolescent (ESSA), sedangkan kuisioner Multidimensional Students' Life Satisfaction Scale-Adolescent (MSLSS) digunakan untuk menilai kualitas hidup. Analisa data menggunakan SPSS versi 24 untuk mengolah analisis univariat yang berupa distribusi frekuensi dari karakteristik responden, dan analisis bivariat untuk mengetahui hubungan antar variabel dengan menggunakan uji Chi-square dengan nilai $\mathrm{p}<0,05$ dinyatakan memiliki hubungan yang signifikan. Penelitian ini dimulai setelah mendapat persetujuan dari komisi etik riset Fakultas Kedokteran Universitas Trisakti.

\section{HASIL}

Tabel 1 menunjukan total responden berjumlah 233 orang. Sebagian besar 
responden berjenis kelamin perempuan (70\%). Peminatan responden terbagi menjadi dua dengan distribusi yang tidak jauh berbeda yaitu IPA $(50,2 \%)$ dan IPS $(49,8 \%)$. Hal serupa juga terlihat pada distribusi jumlah responden pada kelas 10,11 dan 12 .

Tabel 1. Distribusi frekuensi karakteristik responden

\begin{tabular}{ll}
\hline Variabel & $\mathrm{N}(\%)$ \\
$\begin{array}{l}\text { Jenis Kelamin } \\
\text { Laki-laki } \\
\text { Perempuan }\end{array}$ & $70(30 \%)$ \\
Peminatan & $163(70 \%)$ \\
IPA & \\
IPS & $117(50,2 \%)$ \\
Kelas & $116(49,8 \%)$ \\
10 & \\
11 & $78(33,5 \%)$ \\
12 & $77(33 \%)$ \\
\hline
\end{tabular}

Tabel 2. Distribusi subjek berdasarkan stres akademis

\begin{tabular}{ll} 
dan kualitas hidup & \\
\hline Variabel & $\mathrm{N}(\%)$ \\
\hline Stress Akademis & $36(15,5 \%)$ \\
Ringan & $119(51,1 \%)$ \\
Sedang & $78(33,5 \%)$ \\
Berat & \\
Kualitas Hidup & $116(49,8 \%)$ \\
Baik & $117(50,2 \%)$ \\
Kurang & \\
Keluarga & $109(46,8 \%)$ \\
Baik & $124(53,3 \%)$ \\
Kurang & \\
Teman & $99(42,5 \%)$ \\
Baik & $134(57,5 \%)$ \\
Kurang & \\
Sekolah & $107(45,9 \%)$ \\
Baik & $126(54,1 \%)$ \\
Kurang & \\
Lingkungan & $111(47,6 \%)$ \\
Baik & $122(52,4 \%)$ \\
Kurang & \\
Persepsi Diri & \\
Baik & $115(49,4 \%)$ \\
Kurang & $118(50,6 \%)$ \\
\hline
\end{tabular}

Pada tabel 2 dapat dilihat bahwa mayoritas responden memiliki tingkat stres akademis sedang $(51,5 \%)$. Hasi pengukuran kualitas hidup dengan proporsi kualitas hidup baik $(49,8 \%)$ dan kualitas hidup kurang $(50,2 \%)$. Pada tiap domain kualitas hidup juga dapat diamati bahwa proporsi responden yang memilki kualitas hidup kurang dan baik tidak terlalu jauh berbeda.

Pada tabel 3 dapat diamati bahwa remaja dengan tingkat stres akademis berat lebih banyak yang memiliki kualitas hidup kurang $(20,2 \%)$ dibandingkan yang memiliki kualitas hidup baik $(13,3 \%)$ dari total 233 responden. Akan tetapi, remaja dengan tingkat stres akademis sedang lebih banyak yang memiliki kualitas hidup baik (36,6\%). Hasil serupa juga didapatkan pada tingkat stres ringan dengan kualitas hidup baik $(9,9 \%)$. Pada uji statistik dengan menggunakan uji Chi-Square mendapatkan hasil nilai $\mathrm{p}=0,044$ yang berarti terdapat hubungan bermakna antara stres akademis dan kualitas hidup $(\mathrm{p}<$ $0,05)$.

Tabel 3 menggambarkan hasil penilaian dari lima domain kualitas hidup yaitu keluarga, teman, sekolah, lingkungan, dan persepsi diri. Responden dengan tingkat stres sedang $(51,5 \%)$ memiliki kualitas hidup kurang pada setiap domainnya. Responden dengan tingkat stress berat $(33,5 \%)$ cenderung memiliki kualitas hidup kurang, baik secara keseluruhan maupun pada setiap domainnya, kecuali pada domain persepsi diri responden dengan kualitas hidup baik dan kurang berjumlah sama (16,7\%). Responden dengan tingkat stres ringan cenderung memiliki kualitas hidup baik, kecuali pada domain keluarga $(8,6 \%)$ dan domain persepsi diri $(8,2 \%)$, yang mayoritas memiliki kualitas hidup kurang.

Tabel 3 juga menunjukkan hasil uji statistik menggunakan Chi-Square untuk setiap domain dan mendapatkan hasil nilai $\mathrm{p}$ yang bervariasi pada tiap domainnya. Domain keluarga memperoleh hasil $\mathrm{p}=0,828$, domain sekolah memperoleh hasil $\mathrm{p}=0,078$, dan domain persepsi diri memperoleh hasil $\mathrm{p}=$ 0,96 , sehingga dapat disimpulkan tidak adanya hubungan bermakna antara tingkat stress akademis dan kualitas hidup domain keluarga, sekolah, dan persepsi diri dengan. Berbeda dengan domain teman yang memperoleh hasil $\mathrm{p}=0,009$ dan domain lingkungan memperoleh hasil $\mathrm{p}=0,035$, sehingga dapat disimpulkan terdapat hubungan bermakna antara tingkat stress akademis dan kualitas hidup domain temanan dan lingkungan. 
Tabel 3. Hubungan stres akademis dan kualitas hidup pada remaja

\begin{tabular}{|c|c|c|c|c|}
\hline \multirow{2}{*}{ Variabel } & \multicolumn{2}{|c|}{ Kualitas Hidup } & & \multirow{2}{*}{ Nilai $\mathbf{P}$} \\
\hline & Baik & Kurang & Total & \\
\hline \multicolumn{5}{|l|}{ Stres Akademis } \\
\hline Ringan & $23(9,9 \%)$ & $13(5,6 \%)$ & $36(15,5 \%)$ & \\
\hline Sedang & $62(36,6 \%)$ & $57(24,5 \%)$ & $119(51,1 \%)$ & $0,044 *$ \\
\hline Berat & $31(13,3 \%)$ & $47(20,2 \%)$ & $78(33,5 \%)$ & \\
\hline Total & $116(49,8 \%)$ & $117(50,2 \%)$ & $233(100 \%)$ & \\
\hline
\end{tabular}

Kualitas Hidup Keluaraga

\section{Stres Akademis}

Ringan

Sedang

Berat

Total

Stres Akademis

$\begin{array}{ll}\text { Ringan } & 23(9,9 \%) \\ \text { Sedang } & 50(21,5 \%) \\ \text { Berat } & 26(11,2 \%) \\ \text { Total } & 99(42,5 \%)\end{array}$

Stres Akademis

Ringan
Sedang
Berat
Total

Stres Akademis

$\begin{array}{ll}\text { Ringan } & 24(10,3 \%) \\ \text { Sedang } & 55(23,6 \%) \\ \text { Berat } & 32(13,7 \%) \\ \text { Total } & 111(47,6 \%)\end{array}$

$36(15,5 \%)$

$119(51,1 \%) \quad 0,828$

$78(33,5 \%)$

$233(100 \%)$

\section{Kualitas Hidup Teman}

$$
\begin{aligned}
& 13(5,6 \%) \\
& 69(29,6 \%) \\
& 52(22,3 \%) \\
& 134(57,5 \%)
\end{aligned}
$$

$$
\begin{aligned}
& 36(15,5 \%) \\
& 119(51,1 \%) \quad 0,009 * \\
& 78(33,5 \%) \\
& 233(100 \%)
\end{aligned}
$$

\section{Kualitas Hidup Sekolah}

$$
\begin{array}{ll}
22(9,4 \%) & 14(6 \%) \\
55(23,6 \%) & 64(27,5 \%) \\
30(12,9 \%) & 48(20,6 \%) \\
107(45,9 \%) & 126(54,1 \%)
\end{array}
$$

$36(15,5 \%)$
$119(51,1 \%) \quad 0,078$
$78(33,5 \%)$
$233(100 \%)$

\section{Kualitas Hidup Lingkungan}

\section{Stres Akademis}

\section{Kualitas Hidup Persepsi Diri}

$\begin{array}{lllll}\text { Ringan } & 17(7,3 \%) & 19(8,2 \%) & 36(15,5 \%) & \\ \text { Sedang } & 59(25,3 \%) & 60(25,8 \%) & 119(51,1 \%) & 0,96 \\ \text { Berat } & 39(16,7 \%) & 39(16,7 \%) & 78(33,5 \%) & \\ \text { Total } & 115(49,4 \%) & 118(50,6 \%) & 233(100 \%)\end{array}$

* = uji chi square 


\section{PEMBAHASAN}

Pada penelitian ini didapatkan bahwa mayoritas responden berada pada tingkat stres akademis sedang $(51,1 \%)$. Hal ini dapat disebabkan usia responden yang berkisar antara 14-18 tahun yang merupakan usia masa transisi sehingga responden menjadi lebih rentan terhadap stres. ${ }^{(8)}$ Meskipun demikian, terdapat pula responden yang berada pada tingkat stres akademis yang rendah dan tinggi. Perbedaan ini terjadi akibat adanya persepsi setiap individu yang berbeda terhadap stres, sehingga respon dan mekanisme coping terhadap stres tersebut juga akan berbeda. ${ }^{(21)}$ Jenjang pendidikan juga memiliki pengaruh dalam tingkat stres. Berdasarkan penelitian sebelumnya yang dilakukan oleh Thu et $\mathrm{al}^{(9)}$ pada siswa SMP, yang termasuk jenjang pendidikan dasar, didapatkan hasil mayoritas responden mengalami stres ringan. Hasil tersebut berbeda dengan hasil pada penelitian ini, yang menemukan mayoritas responden mengalami stres sedang $(51,1 \%)$. Hal ini mungkin disebabkan oleh adanya perbedaan sistem pendidikan di SMA dan SMP. Di SMA diberikan penambahan kurikulum dan persiapan untuk melanjutkan pendidikan ke universitas, sehingga terjadi penambahan beban materi pembelajaran dan tekanan psikologis yang lebih besar. Kedua hal tersebut merupakan faktor yang dapat menyebabkan stres. ${ }^{(2)}$

Pada penelitian ini didapatkan bahwa mayoritas responden berada pada tingkat kualitas hidup kurang (50,2\%). Akan tetapi, hasil ini tidak jauh berbeda dengan kualitas hidup baik (49,8\%). Perbedaan ini mungkin terjadi akibat adanya faktor-faktor protektif ${ }^{(23)}$, proses adaptasi psikologis dan resistensi terhadap stres $^{(24)}$ yang mempengaruhi kemampuan masing-masing individu dalam menghadapi stresor maupun untuk kembali ke kondisi sebelum terpajan stressor (resilience). (25) Kemampuan inilah yang kemudian dapat mempengaruhi kualitas hidup individu tersebut. ${ }^{(26)}$

Kualitas hidup yang dinilai pada penelitian ini terdiri dari lima domain yaitu domain keluarga, teman, sekolah, lingkungan, persepsi diri. Pada domain keluarga didapatkan hasil lebih banyak responden yang memiliki kualitas hidup kurang $(53,2 \%)$. Hal ini dapat dipengaruhi oleh hubungan antara remaja dan orang tua. Pada masa ini, remaja masih memerlukan figur suportif dari orang tuanya. Dukungan dan kedekatan dengan orang tua dapat mempengaruhi kualitas hidup remaja. ${ }^{(27)}$ Berbagai perubahan terjadi pada masa remaja, seperti perubahan biologis dan perkembangan kognitif. Adanya perubahantersebut menyebabkan remaja menuntut untuk lebih mandiri dan juga memilki pemikiran sendiri yang berbeda dengan orang tuanya. Hal ini dapat memicu terjadinya konflik antara orang tua dan remaja sehingga hubungan antara keduanya menjadi lebih renggang. ${ }^{(28)}$ Selain itu, pada masa ini, remaja juga cenderung menghabiskan lebih banyak waktu dengan teman sebayanya ${ }^{(27)}$, sehingga waktu yang dihabiskan bersama orang tua dan keluarga berkurang.

Pada domain teman didapatkan hasil lebih banyak responden yang memiliki kualitas hidup kurang (57,7\%). Pada masa remaja, terdapat keinginan untuk disukai dan diterima oleh teman sebaya. Hal ini menyebabkan remaja sangat memikirkan pandangan temannya terhadap dirinya. Hubungan dengan teman sebaya pada masa remaja dapat mempengaruhi kualitas hidup remaja tersebut. ${ }^{(27)}$

Pada domain sekolah didapatkan hasil lebih banyak responden yang memiliki kualitas hidup kurang $(54,1 \%)$. Hal ini dapat dipengaruhi oleh perubahan kurikulum dari pemerintah, yaitu kurikulum 2013 yang sekarang berlaku. Pada kurikulum ini, terdapat penambahan jam belajar tiap kenaikan tingkat dan murid juga dituntut untuk menjadi lebih aktif dalam mencari bahan pelajaran. (29) Perubahan kurikulum ini menyebabkan penambahan beban materi bagi siswa, sehingga siswa semakin merasa terbebani dengan sekolah.

Pada domain lingkungan didapatkan hasil lebih banyak responden yang memiliki kualitas hidup kurang (52,4\%). Pada penelitian ini, mayoritas responden tinggal di daerah pemukiman yang padat penduduk dan 
lingkungan yangkurang terjaga kebersihannya. Kondisi lingkungan tempat tinggal dapat mempengaruhi kualitas hidup. Lingkungan yang bersih, ketersediaan air bersih, dan banyaknya pepohonan di lingkungan sekitar tempat tinggal dapat meningkatkan kualitas hidup individu. ${ }^{(30)}$

Pada domain persepsi diri didapatkan hasil lebih banyak responden yang memiliki kualitas hidup kurang $(50,6 \%)$. Persepsi diri remaja dipengaruhi oleh dukungan orang tua dan penerimaan dari teman sebayanya. (31) Pada penelitian ini diperoleh hasil proposi yang lebih banyak pada kualitas hidup kurang di domain keluarga dan teman. Hal inilah yang mungkin menyebabkan juga lebih banyaknya responden yang memilki kualitas hidup kurang pada domain persepsi diri. Selain itu, pada usia remaja juga terdapat kebiasaan untuk membandingkan kemampuan dan penampilan dirinya dengan orang lain yang berada dalam lingkungannya yang kemudian menimbulkan efek negatif seperti menjadi mudah terpengaruh dan kurang percaya diri. (32)

\section{Aksis hypothalamic-pituitary-adrenal} (HPA) mengatur reaksi tubuh terhadap stress. Dalam merespon stresor, hipotalamus akan menghasilkan corticotropin releasing hormone ( $\mathrm{CRH})$ yang akan berikatan dengan sel-sel di hipofisis dan menghasilkan adenocorticotropic hormone (ACTH) dan selanjutnya merangsang kelenjar adrenal untuk meningkatkan memproduksi hormon kortisol, efinefrin dan norefinerin. Hormon tersebut akan meningkatkan frekuensi detak jantung, laju pernapasan, tekanan darah, dan metabolisme tubuh. ${ }^{(33-35)}$

Pada remaja terjadi berbagai perubahan pada tubuhnya, salah satunya adalah perkembangan bagian otak korteks pre-frontal, amigdala, dan striatum ventralis. Bagian otak yang sedang berkembang ini lebih banyak mengandung hormon-hormon yang berperan pada stress dibandingkan individu dewasa. Hal inilah yang merupakan salah satu penyebab remaja lebih rentan untuk mengalami stress. ${ }^{(36)}$ Ketika remaja mengalami stres dalam jangka panjang meskipun dengan tingkat stres yang ringan, kondisi ini dapat mempengaruhi sistem imun, sistem pencernaan ${ }^{(37)}$, mood dan emosi, kemampuan konsenterasi ${ }^{(37,38)}$, dan memori. (38) Perubahan yang terjadi akibat kondisi ini dapat menyebabkan penurunan kesehatan fisik, kondisi psikologis, dan hubungan sosial, sehingga dapat mengakibatkan penurunan kualitas hidup. ${ }^{(16,17)}$

Stres akademis merupakan salah satu jenis stres yang dapat terjadi pada remaja. Stres yang dialami dalam jangka waktu yang lama dapat mengakibatkan kelelahan fisik dan emosional. Kondisi ini disebut sebagai burnout. $^{(39,40)}$ Kondisi ini selanjutnya akan mempengaruhi kualitas hidup. ${ }^{(41,42)}$

Pada penelitian ini, dilakukan pengolahan data dengan program SPSS menggunakan uji Chi-square untuk menentukan hubungan antara stres akademis dan kualitas hidup pada remaja. Hasil menunjukkan nilai $\mathrm{p}=0,044$, sehinga dapat diartikan bahwa terdapat hubungan yang bermakna antara stres akademis dan kualitas hidup pada remaja $(\mathrm{p}<0,05)$. Hasil ini selaras dengan penelitian sebelumnya yang dilakukan oleh Awadh et al ${ }^{(17)}$ mengenai persepsi stres dan kualitas hidup. Pada penelitian tersebut didapatkan hasil uji dengan nilai $p<0,01$. Hasil ini diperkuat oleh penelitian Lyndon et al ${ }^{(19)}$ yang menyatakan bahwa mahasiswa dengan tingkat burnout tinggi cenderung memiliki kualitas hidup yang rendah, dan berisiko mengalami penurunan nilai, kecemasan, dan hilangnya motivasi.

Kualitas hidup yang dinilai pada penelitian ini terdiri dari lima domain yaitu keluarga, teman, sekolah, lingkungan, dan persepsi diri. Sebuah studi yang dilakukan oleh Acheampong et $\mathrm{al}^{(43)}$ menyatakan bahwa stres memiliki hubungan dengan kualitas hidup dengan penilaian pada domain hubungan sosial, kesehatan lingkungan, kesehatan fisik, dan kesehatan psikologis. Hasil tersebut sejalan dengan temuan pada penelitian ini, bahwa stres akademis memiliki hubungan dengan kualitas hidup domain teman $(p=0,009)$ dan domain lingkungan $(p=$ 0,035 ). Perbedaan hasil pada domain lainnya dapat disebabkan oleh perbedaan jenis stres yang dinilai. Penelitian Acheampong et $\mathrm{al}^{(43)}$ 
menilai persepsi responden terhadap tingkat stres secara umum dan kemampuan untuk mengatasinya, sedangkan pada penelitian ini terbatas pada stres yang disebabkan oleh stresor akademis.

Berbeda dengan penelitian yang dilakukan oleh Marshall et al di Amerika Serikat yang dilakukan pada mahasiswa farmasi. Pada penelitian ini didapatkan hasil bahwa stres tidak memiliki hubungan dengan kualitas hidup terkait kesehatan fisik. Nilai kualitas hidup mahasiswa yang menjadi responden pada penelitian tersebut lebih tinggi dibandingkan nilai rata-rata penduduk nasional. Hasil ini dapat dipengaruhi oleh usia responden yang berkisar dibawah 30 tahun, dan kebiasaan yang dipilih untuk mengatasi stres yaitu berolahraga ${ }^{(20)}$

Kualitas hidup, selain dipengaruhi oleh stress, juga dipengaruhi oleh berbagai faktor lainnya. Penelitian ini berfokus pada hubungan antara stress akademis dan kualitas hidup pada remaja, sehingga responden yang memiliki faktor-faktor lain diluar stressor akademis dieksklusikan. Adanya penyakit kronis merupakan salah satu faktor yang dapat menurunkan kualitas hidup. Akan tetapi, pada penelitian ini ada tidaknya riwayat penyakit kronis hanya dapat diketahui melalui kuisioner tanpa dilakukan pemeriksaan yang sesuai ataupun melihat data rekam medis dari responden.

\section{KESIMPULAN}

Pada penelitian ini dapat ditarik kesimpulan adanya hubungan signifikan antara stress akademis dan kualitas hidup pada remaja dengan nilai $\mathrm{p}=0,044$.

\section{UCAPAN TERIMA KASIH}

Sekolah SMAN 1 Cileungsi yang telah mengizinkan dilakukannya penelitian ini dan membantu dalam proses pengambilan data.

\section{DAFTAR REFERENSI}

1. World Health Organization. Maternal, newborn, child and adolescent health. Available at : http://www.who.int/ maternal_child_adolescent/topics/ adolescence/dev/ Accessed on May 5, 2017.

2. Kementerian Kesehatan Republik Indonesia. Situasi Kesehatan Reproduksi Remaja. Pusat Data dan Informasi Kementerian Kesehatan RI. Jakarta. 2015.p.1

3. Wagiran DI, Kaunang WP, Wowor VN. Kualitas hidup remaja SMAN 6 Manado yang mengalami maloklusi. JKKT 2014; $2: 86$.

4. United Nation Development Programmes. Laporan Pembangunan Manusia. 2016. Available at : http://www.id.undp. org/content/dam/indonesia/2017/doc/ INS- HDR2016\%20indonesia\%20 summary-final.pdf. Accessed on May 20, 2017.

5. World Health Organization. Health Statistic and Information Systems. Available at : http://www.who.int/ healthinfo/survey/whoqol-qualityoflife. Accessed on May 5, 2017.

6. Isfandari S. Pendidikan dan pekerjaan berdasarkan kualitas hidup pada remaja (gambaran deskriptif data RISKESDAS 2007). Jurnal Ekologi Kesehatan 2009;8:1108-16. Available at: http:// ejournal.litbang.depkes.go.id/index.php/ jek/article/view/1688/952. Accesed on May 20, 2017.

7. Muhaimin. Mengukur kualitas hidup anak. J Kes Mas Nas 2010;5:51-5. DOI: http:// dx.doi.org/10.21109/kesmas.v5i2.1488

8. Nurmaliya F. Menurunkan stres akademik siswa dengan menggunakan teknik self instruction. Jurnal Pendidikan Humaniora 2014;2:273-82. Available at: http:// journal.um.ac.id/index.php/jph/article/ viewFile/4469/951. Accesed on May 21, 2017.

9. Thu DT, Thao DT, Toan PP, et al Academic stress and its associations to some factor among secondary school students in 
the central of Vietnam. J Med Pharm 2012;2:86-91

10. Sun J, Dunne MP, Hou X, et al. Educational stress scale for adolescents: development, validity, and reliability with Chinese student. J Psychoeduc Assess 2011;29:53446. DOI: $10.1177 / 0734282910394976$.

11. Deb S, Strodi E, Sun J. Academic stress, parental pressure, anxiety and mental health among Indian high school students. Int J Psychol Behav Sci 2015;5:26-34. doi:10.5923/j.ijpbs.20150501.04.

12. North B, Gross M, Smith S. Study confirms HSC exams source of major stres to adolescents. University

of New South Wales. 2015. Available at : http://newsroom.unsw.edu.au/ news/social-affairs/study-confirms-hscexams-source- major-stress-adolescents . Accessed on May 28, 2017.

13. Kleiveland B, Natvig GK, Jepsen R. Stres, sense of coherence and quality of life among Norwegian nurse students after a period of clinical practice. PeerJ 2015;3:1286. Available at : https://doi. org/10.7717/peerj.1286. Accessed on May, 222017.

14. American Psychological Association. Understanding chronic stres. Available at : http://www.apa.org/helpcenter/ understanding-chronic-stres.aspx. Accessed on May 5, 2017.

15. Mayo Clinic. Stres symptoms: Effects on your body and behavior. Available at : http://www.mayoclinic.org/healthylifestyle/stres-management/in-depth/ stres- symptoms/art-20050987 . Accessed on May 25, 2017.

16. Simon H, Zieve D. Stres. Available at : http://www.umm.edu/health/medical/ articles/stres. Accessed on May 25, 2017.

17. Awadh AI, Azis NA, Yaseen SN, et al. A comparison study of perceived stress and quality of life among master of pharmacy and non-pharmacy master students. Pharm Ed 2013;13: 22-8.

18. Ribeiro ÍJS, Pereira R, Freire IV, et al. Stres and quality of life among university students: a systematic literature review. Health Prof Edu 2017. Available at : http:// dx.doi.org/10.1016/j.hpe.2017.03.002. Accessed on May 25, 2017.

19. Lyndon MP, Henning MA, Alyami H, et al. Burnout, quality of life, motivation, and academic achievement among medical students. Perspect Med Edu 2017;6:10814. doi: 10.1007/s40037-017-0340-6.

20. Marshall LL, Allison A, Nykamp D, et al. Perceived stress and quality of life among doctor of pharmacy students. Am J Pharm Educ 2008;72:137.

21. Leonard NR, Gwadz MV, Ritchie A, et al. A multi-method exploratory study of stress, coping, and substance use among high school youth in private schools. Front Psychol 2015;6:1028. doi:10.3389/ fpsyg.2015.01028.

22. Çakır S, Akça F , Kodaz AF, et al. The survey of academic procrastionation on high school students with in terms of school burn-out and learning styles. Procedia Soc Behav Sci 2014;114:654 62. doi: 10.1016/j.sbspro.2013.12.763.

23. Dolbier CL, Smith SE, Steinhardt MA. Relationships of protective factors to stress and symptoms of illness. Am J Health Behav. 2007;31:423-33.

24. Jabbarov R, Mustafayev M, Ibrahimova $\mathrm{D}$, et al. The characteristics of social and psychological adaptation and stress resistance of idps living in Baku city and its surrounding districts. Int J Sci Res 2016;5:1715-21. DOI: 10.21275/ ART20161303.

25. Diehl M, Hay EL, Chui H. Personal risk and resilience factors in the context of daily stress. Annu Rev Gerontol Geriatr 2012;32:251-74. doi:10.1891/01988794.32.251.

26. Abolghasemia A, Varaniyaba ST. Resilience and perceived stress: predictors of life satisfaction in the students of success and failure. Procedia Soc Behav Sci 2010;5:748-52. doi:10.1016/j. sbspro.2010.07.178.

27. Schwarz B, Mayer B, Trommsdorff G, et al. Does the importance of parent and peer relationships for adolescents' life satisfaction vary across cultures? J Early Adolesc 2012;32:55-80. DOI: 


\section{$10.1177 / 0272431611419508$.}

28. Susan Branje. Development of parentadolescent relationships: conflict interactions as a mechanism of change. Child Dev Perspect 2018;0:1-6. DOI: 10.1111/cdep.12278.

29. Kementerian pendikan dan kebudayaan. 2013. Kurikulum 2013 kompetensi dasar sekolah mengah atas (SMA)/ madrasah Aliyah (MA). Jakarta. Available at: https://docs.google.com/file/ d/0B2qLrZkRe9a2Mm14TU96azBINlk/ edit. Accessed on June 11, 2018.

30. Streimikiene D. Environmental indicators for the assessment of quality of life. Intellectual Economics. 2015;9:67-79. https://doi.org/10.1016/j. intele.2015.10.001.

31. Manning MA. Self-Concept and Self-Esteem in Adolescents. Student Services, National Association of School Psychologist;2007. Available at: http://www.nasponline.org/search/ search-results ?keywords =Self$\mathrm{C}$ o n c e p t $+\mathrm{and}+\mathrm{S}$ e $1 \mathrm{f}$ Esteem+in+Adolescents. Accessed on June 10, 2018.

32. Brighton KL. Coming of age: The education and development of young adolescents. Ohio: National Middle School Association; 2007.

33. Guilliams TG, Edwards L. Chronic stress and the HPA axis: clinical assessment and therapeutic considerations. The Standard. 2010;9:12p. Available at: http:// www.pointinstitute.org/wp-content/ uploads/2012/10/standard_v_9.2_hpa axis.pdf. Accessed on June 10, 2018.

34. Feijó de Mello AA, Feijó de Mello M, Carpenter LL, et al. Update on stress and depression: the role of the hypothalamicpituitary-adrenal (HPA) axis. Rev Bras Psiquiatr 2003;25(4):231-8. http://dx.doi. org/10.1590/S1516-44462003000400010.

35. Tomas C, Newton J, Watson S. A review of hypothalamic-pituitary-adrenal axis function in chronic fatigue syndrome. Neuroscience 2013;2013:8p. http://dx.doi. org/10.1155/2013/784520.

36. Tottenham N, Galván A. Stress and the adolescent brain: amygdala-prefrontal cortex circuitry and ventral striatum as developmental targets. Neurosci Biobehav Rev. 2016;70: 217-27. doi:10.1016/j. neubiorev.2016.07.030.

37. Salleh MR. Life event, stress and illness. Malays J Med Sci. 2008 Oct;15:9-18.

38. Sheth C, McGlade E, Todd DY. Chronic stress in adolescents and its neurobiological and psychopathological consequences: an rdoc perspective. Chronic Stress 2017;1:122. DOI: $10.1177 / 2470547017715645$.

39. Chang KH, Lu FJH, Chyi T, et al, Examining the stress-burnout relationship: the mediating role of negative thoughts. PeerJ 2017;5:e4181. DOI 10.7717/ peerj.4181.

40. Marin JM, Abril JP, Demarzo MMP, et al. Coping with stress and types of burnout: explanatory power of different coping strategies. Plos one 2014;9:e89090. https:// doi.org/10.1371/journal.pone.0089090.

41. Anand M, Arora D. Burnout, life satisfaction and quality of life among executives of multi national companies. JIAAP 2009;35:159-64.

42. Pagnin D, Queiroz V. Influence of burnout and sleep difficulties on the quality of life among medical students. SpringerPlus 2015;4:676. DOI 10.1186/s40064-0151477-6.

43. Acheampong AO, Kretchy IA, Acheampong F, et al. Perceived stress and quality of life of pharmacy students in university of Ghana. BMC Res Notes 2017;10:115. DOI 10.1186/s13104-0172439-6. 